\title{
Bacterial and Fungal Infections Among Diabetics
}

\author{
SOLIMAN M. El-SHEIKH, PhD* and AYMAN K. JOHARGI ${ }^{* *}$ \\ *Department of Microbiology, Faculty of Medicine \& Allied Sciences, King Abdulaziz \\ University, Jeddah, Saudi Arabia and ${ }^{* *}$ Department of Microbiology, College \\ of Medicine, Ommu Al-Qura University, Makkah, Saudi Arabia
}

\begin{abstract}
One hundred and fifty specimens were collected from diabetic patients suffering from infections over a period of 9 months. Urine was the most frequently collected specimen from diabetic patients $(50 \%)$ followed by foot swabs $(24 \%)$, tracheal aspiration and sputum $(12.7 \%)$, blood $(6.7 \%)$, vaginal swabs (3.3\%), and eye swabs and each stool represented $1.3 \%$. A wide variety of gram-negative bacteria representing 12 different species were identified as the etiologic agents of infections in these specimens. Clearly, E. coli dominated over all the other species. Among the 150 microbes causing infections in diabetic patients, a total of $40(26.7 \%)$ were identified as E. coli. Pseudomonas aeruginosa were the second bacterial species causing infections. They were isolated from 20\%, followed by Klebsiella pneumoniae (9.3\%), and Proteus mirabilis (4.7\%). Salmonella, Enterobacter, Acinetobacter, and Citrobacter were found in $2 \%$ of the cases. Morganella (1.3\%) and Serratia were detected in less than $1 \%$. Among gram-positive bacteria, Staphylococci were the most frequent organisms and were isolated from $20(13.3 \%)$ specimens. Other gram-positive bacteria were Streptococcus (4\%), Enterococcus faecalis $(2 \%)$, Micrococcus 2 (1.3\%), and Diphtheroids were detected in less than $1 \%$. Candida albicans and Candida spp. were isolated from 12 diabetic patients.
\end{abstract}

Keywords: Bacteria, Fungi, Diabetic patients.

\section{Introduction}

Diabetic patients are more susceptible to bacterial and fungal infections and urinary

Correspondence \& reprint requests to: Dr. S. M. El-Sheikh, P.O. Box 80215, Jeddah 21589, Saudi Arabia. Accepted for publication: 8 June 1998. Received: 30 March 1998 
tract infections (UTI) have long been recognized as a significant problem in patients with Diabetes mellitus. Studies documented a two-to-threefold increase in this problem in diabetic women ${ }^{[1]}$. Kass ${ }^{[2]}$ documented a $16-19 \%$ rate of bacteriuria in diabetic women compared to 5-8\% in non-diabetic women.

Diabetics also have an increased propensity to develop soft tissue infections. In patients with Diabetes mellitus, soft tissue and bone infection of the lower limbs is the most common cause for hospital admission ${ }^{[3]}$. The rate of lower extremity amputation among diabetics is more than 40 times that of non-diabetics ${ }^{[4]}$.

Lower respiratory tract infections were common in diabetic patients and diabetes is often identified as an independent risk factor for developing these infections ${ }^{[5]}$. Although the mortality from infection has decreased with the advent of insulin therapy and broad spectrum antimicrobial agents, pneumonia remains a significant cause of morbidity in the diabetic patient ${ }^{[6]}$. The purpose of this study was to identify the most common organisms causing superficial and deep infections in Saudi diabetics.

\section{Materials and Methods}

One hundred and fifty different specimens were collected from diabetic patients (61 males and 89 females) from the King Khalid National Guard Hospital in Jeddah, Saudi Arabia, over a period of 9 months. The specimens were transported to the bacteriology laboratory in the Microbiology Department, Faculty of Medicine \& Allied Sciences, King Abdulaziz University, Jeddah, Saudi Arabia, and were processed without delay.

Specimens except urine and stools were cultured in the following agar media: sheep blood, chocolate, and MacConkey \& Sabouraud's dextrose agar.

Urine specimens were cultured in cystine lactose electrolyte deficient media (CLED) and MacConkey agar. Stool specimens were cultured in deoxycholate citrate agar (DCA), xylose lysine desoxycholate agar (XLD), and MacConkey.

The culture plates were incubated aerobically at $37^{\circ} \mathrm{C}$ (under $5 \% \mathrm{CO}_{2}$, chocolate blood agar) and examined at 24 and $48 \mathrm{~h}$. For anaerobic cultures, the specimens were inoculated onto blood agar containing kanamycin and vancomycin $(75 \mu \mathrm{g} / \mathrm{ml}$ and 7.5 $\mu \mathrm{g} / \mathrm{ml}$, respectively). This media was incubated in Gas Pak (BBL) jars at $37^{\circ} \mathrm{C}$ and examined after 48 and $96 \mathrm{~h}$ of incubation. Aerobic bacteria were identified according to standard methods $^{[7]}$. Anaerobic bacteria were identified by techniques described previously ${ }^{[8]}$.

\section{Results}

Distribution of Infections: In this study 150 specimens were collected from diabetic patients (61 males and 89 females) suffering from infections over a period of 9 months. Urine was the most frequently collected specimen from diabetic patients $(50 \%)$ followed by foot swabs (24\%), tracheal aspiration and sputum (12.7\%), blood 
(6.7\%), vaginal swabs $(3.3 \%)$, and eye swabs and each stool represented $1.3 \%$ (Table 1 , Fig. 1).

TABLE 1. Distribution of organisms according to types of specimens among 150 diabetic patients.

\begin{tabular}{|l|c|c|c|c|c|c|c|c|c|}
\hline \multicolumn{1}{|c|}{ Organism } & Urine & $\begin{array}{c}\text { Wound } \\
\text { (Foot) } \\
\text { Swab }\end{array}$ & Sputum & Blood & $\begin{array}{c}\text { Eye } \\
\text { Swab }\end{array}$ & $\begin{array}{c}\text { Tracheal } \\
\text { Aspiration }\end{array}$ & $\begin{array}{c}\text { High } \\
\text { Vaginal } \\
\text { Swab }\end{array}$ & Stool & Total \\
\hline E. coli & 35 & 2 & 1 & 2 & -- & -- & -- & -- & 40 \\
\hline Staph. aureus & 3 & 9 & 4 & 1 & 1 & 1 & 1 & -- & 20 \\
\hline Pseudomonas & 6 & 18 & 3 & -- & 1 & 2 & -- & -- & 30 \\
\hline Klebsiella p. & 9 & -- & 4 & -- & -- & 1 & -- & -- & 14 \\
\hline Streptococcus & 2 & 3 & -- & 1 & -- & -- & -- & -- & 6 \\
\hline Acinetobacter & -- & -- & -- & 1 & -- & 2 & -- & -- & 3 \\
\hline Enterobacter & 1 & 2 & -- & -- & -- & -- & -- & -- & 3 \\
\hline Enterococcus & 2 & 1 & -- & -- & -- & -- & -- & -- & 3 \\
\hline Morganella & 1 & -- & -- & 1 & -- & -- & -- & -- & 2 \\
\hline Salmonella & 1 & -- & -- & -- & -- & -- & -- & 2 & 3 \\
\hline Micrococcus & -- & -- & -- & 2 & -- & -- & -- & -- & 2 \\
\hline Diphtheroid & -- & -- & -- & 1 & -- & -- & -- & -- & 1 \\
\hline Serratia & 1 & -- & -- & -- & -- & -- & -- & -- & 1 \\
\hline Staph. waneri & -- & -- & -- & 1 & -- & -- & -- & -- & 1 \\
\hline Citrobacter & -- & -- & -- & -- & -- & 2 & -- & -- & 3 \\
\hline Proteus & 6 & 1 & -- & -- & -- & -- & -- & -- & 7 \\
\hline Candida & 8 & -- & -- & -- & -- & -- & 4 & -- & 12 \\
\hline Total Specimens & 75 & 36 & 12 & 10 & 2 & 8 & 5 & 2 & 150 \\
\hline
\end{tabular}

Bacterial Infections: The distribution of gram-negative bacterial species causing infections in diabetic patients is shown in Table 2. A wide variety of gram-negative bacteria representing 12 different species were identified as the etiologic agents of infections. Clearly, E. coli was predominant over all other species. Among the 150 microbes causing infections in diabetic patients, a total of $40(26.7 \%)$ were identified as E. coli. The second bacterial species causing infections in diabetic patients was Pseudomonas aeruginosa isolated from $20 \%$ followed by Klebsiella pneumoniae (9.3\%), and Proteus mirabilis (4.7\%). Salmonella, Enterobacter, Acinetobacter, Citrobacter were found in two of the cases, Morganella $(1.3 \%)$, and Merratia $(<1 \%)$.

Among gram-positive bacteria, Staphylococci were the most frequent organisms encountered and were isolated from $20(13.3 \%)$ of the specimens. Other gram-positive bacteria detected were: Streptococci (4\%), Enterococcus faecalis (2\%), Micrococci $(1.3 \%)$, and Diphtheroid $(<1 \%)$ (Table 2). 
TABLE 2. Distribution of bacterial and fungal species isolated from different sites from 150 diabetic patients.

\begin{tabular}{|c|c|}
\hline Organism & Number of Strains (\%) \\
\hline E. coli & $40(26.7)$ \\
\hline Pseudomonas aeruginosa & $30(20)$ \\
\hline Staphylococcus aureus & $20(13.3)$ \\
\hline Klebsiella pneumoniae & $14(9.3)$ \\
\hline Proteus mirabilis & $7(4.7)$ \\
\hline Streptococcus agalactica (beta haemolytic) group B & $1(0.7)$ \\
\hline Streptococcus pyogenes (beta haemolytic) group A & $4(2.7)$ \\
\hline Streptococcus (beta haemolytic) group G & $1(0.7)$ \\
\hline Enterococcus faecalis & $3(2)$ \\
\hline Enterobacter cloacae & $2(1.3)$ \\
\hline Enterobacter sakazakii & $1(0.7)$ \\
\hline Salmonella species & $3(2)$ \\
\hline Micrococcus & $2(1.3)$ \\
\hline Morganella morganii & $2(1.3)$ \\
\hline Diphtheroids & $1(0.7)$ \\
\hline Serratia marcescense & $1(0.7)$ \\
\hline Staphylococcus waneri & $1(0.7)$ \\
\hline Acinetobacter cloacae & $3(2)$ \\
\hline Citrobacter diversus & $1(0.7)$ \\
\hline Citrobacter freundii & $1(0.7)$ \\
\hline Candida albicans & $4(2.7)$ \\
\hline Candida tropicalis & $2(1.3)$ \\
\hline Candida famata & $2(1.3)$ \\
\hline Candida glabrata & $2(1.3)$ \\
\hline Candida colliculosa & $1(0.7)$ \\
\hline Candida parapsilosis & $1(0.7)$ \\
\hline Total Specimens & $150(100 \%)$ \\
\hline
\end{tabular}

Fungal Infections: Candida were isolated from $12(8 \%)$ diabetic patients. They were identified as Candida albicans (2.7\%), Candida tropicalis (1.3\%), Candida famata (1.3\%), Candida glabrata (1.3\%), and Candida colliculosa and Candida parapsilosis each were found in one of the cases $(0.7 \%)$ (Table 2). 


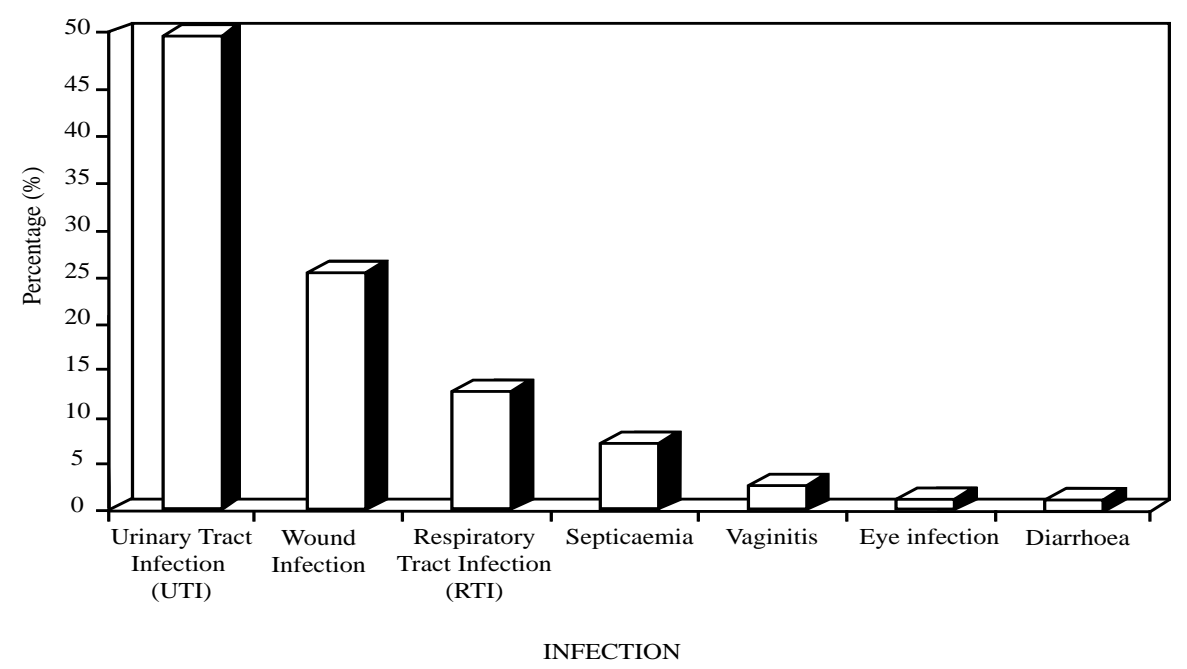

Fig. 1. Distribution of infections among 150 diabetic patients.

\section{Discussion}

Urinary tract infection (UTI) has long been recognized as a significant problem in patients with Diabetes mellitus. Variable rates of uncomplicated UTI in diabetics have been reported in studies performed since the advent of quantitative microbiology. Some early studies showed no difference between the frequency of UTI in diabetics compared to controls ${ }^{[9]}$. But more recent studies documented a two-to-threefold increase of this problem in diabetic women ${ }^{[10]}$. Kass ${ }^{[2]}$ documented a 16-19\% rate of bacteriuria in diabetic women compared to $5-8 \%$ in nondiabetic women.

In the present study we found that UTI were common in diabetic patients. UTI accounts for $50 \%$ of the infections (20\% in males and $30 \%$ in females). Gram-negative bacteria was the most common bacterial pathogens isolated from diabetic patients with UTI (82\%) (Table 2). E. coli caused the majority of UTI $(46.7 \%$ followed in descending frequency with Klebsiella pneumoniae (12\%); Pseudomonas and Proteus each accounting for 8\%; and Enterobacter, Salmonella, Serratia, and Morganella each $1.35 \%$. Previous studies have shown that $E$. coli is the most common bacterial cause of UTI in diabetics; other Coli forms such as Klebsiella pneumoniae and Proteus mirabilis also are common. Infections due to Enterobacter spp., Enterococcus spp., and Pseudomonas aeruginosa should be considered in diabetics who are hospitalized or have had recent urologic procedures. Enterobacter spp infection has been observed to be mainly community acquired ${ }^{[11,12]}$ and Enterococcus spp and Pseudomonas aeruginosa should be considered in patients in the community who have recently received antimicrobial agents. Diabetic patients were also prone to get urinary tract Candidiasis. These results showed that Candidiasis represented $10.7 \%$ of UTI. 
Surveillance programs and several authors suggest an increase in Candida species as a cause of UTI ${ }^{[12,13]}$. Fisher et $a l^{[14]}$ demonstrated that concomitant antibiotic administration, urinary tract instrumentation, and previous bacteriuria were significant risk factors for Candiduria in both catheterized and uncatheterized patients including diabetic patients.

Our data showed that foot infections among diabetic patients accounted for $24 \%$ of infection and came second to urinary tract infection. Studies showed that in patients with Diabetes mellitus, soft tissue and bone infection of the lower limbs is the most common indication for hospital admission ${ }^{[3]}$. Diaz-Colodrero et al ${ }^{[15]}$ in Spain evaluated 31 diabetic patients hospitalized for severe foot infection and found that $56 \%$ of the cases were caused by gram-positive cocci (predominantly Staphylococcus aureus and Enterococcus) and $43 \%$ of the cases were caused by gram-negative Bacilli. Comparing this study, our result showed that Staphylococci and Streptococci account for $36.1 \%$ of the foot infections but gram-negative bacteria, in particular Pseudomonas aeruginosa, occur in $63.9 \%$ of the cases. However, the $63.9 \%$ of the gram-negative $\mathrm{Ba}$ cilli isolated in our study was higher than that reported elsewhere $(50 \%)^{[16,17,18]}$.

Our study clearly showed that lower respiratory tract infections came after urinary tract and foot infections in rank and account for $8.7 \%$ as a common cause of infections.

Pneumonia remains a significant cause of morbidity in the diabetic patient. Gramnegative aerobes cause approximately $10-20 \%$ of all community-acquired Pneumonia and $60-80 \%$ of all nosocomial pneumonias ${ }^{[19]}$. The majority of Pneumonias caused by gram-negative aerobes in diabetic hosts are members of the Enterobacteriaceae family which include E. coli, Enterobacter, Klebsiella spp., and Serratia, as well as, the pseudomonal species such as Pseudomonas aeruginosa ${ }^{[19]}$. This is in line with our finding that the majority of Pneumonia caused by gram-negative aerobes in diabetic patients were members of the Enterobacteriaceae family.

It is hoped that this data will give some guidance to physicians in the community who frequently have to deal with infections in diabetics. Thus, the micro-organisms isolated in this study should be targeted in any study in the future.

\section{Acknowledgment}

I thank Professor A. O. Osaba, Consultant Microbiologist, King Khalid National Guard Hospital, Jeddah, Saudi Arabia, for critical review of the manuscript.

\section{References}

[1] Forland M, Thomas V, Shelokov A. Urinary tract infections in patients with Diabetes mellitus: Stud ies on antibody coating of bacteria. JAMA 1977; 238(18): 1924-1926.

[2] Kass EH. Asymptomatic infections of the urinary tract. Trans Assoc Am Physicians 1956; 69: 56-60.

[3] Gibbons GW, Eliopoulos GM. Infection of the diabetic foot. In: Kozak GO, Hoar CS, Rowbotham JL et al, eds. Management of diabetic foot problems. Philadelphia: W.H. Saunders, 1984: 97. 
[4] Centers for Disease Control. Lower extremity amputations among persons with Diabetes mellitus-Washington. MMWR 1991; 40: 737-739.

[5] MacKowiak PA, Martin RU, Smith JW. The role of bacterial interference in the increased prevalence of oropharyngeal gram-negative bacilli among alcoholics and diabetics. Am Rev Respir Dis 1979; 120(3): 589-593.

[6] Younger D, Hadley WB. Infection and diabetes. In: Marbie A, Whilte P, Bradley RF et al, eds. Joslin's Diabetes mellitus, $11^{\text {th }}$ edn., Philadelphia: Lea \& Febiger, 1971; 621.

[7] Hawkey PM, Lewis DA (Editors). Medical bacteriology: a practical approach. Oxford: IRL Press, 1989.

[8] Holdeman LU, Cato EP, Moore WEC (Editors). Anaerobe Laboratory Manual, $4^{\text {th }}$ edition. Virginia Polytechnic Institute and State University, Blacksburg, 1977.

[9] O'Sullivan DJ, Fitzgerald MG, Meynell MJ. Urinary tract infection: a comparative study in the diabetic and general populations. Br Med J 1961; 1: 786-792.

[10] Ooi BS, Chen BTM, Yu M. Prevalence and site of Bacteriuria in Diabetes mellitus. Post Grad Med $J$ 1974; 50(586): 497-499.

[11] Mani S, Edberg SC, Patterson JE. Community-acquired bacteremia due to multiresistent Enterobacter bacteremia in a patient with urosepsis. Clin Inf Dis 1992; 15(3): 565-566.

[12] Frangos DM, Nyberg LM Jr. Genito urinary fungal infections. South Med J 1986; 7(4): 455-459.

[13] Stamm WE. Catheter-associated urinary tract infections: epidemiology, pathogenesis and prevention. Am J Med 1991; 91(3B): 655-751.

[14] Fisher JF, Chew WH, Shadomy S, Duma RJ, Mayhall CG, House WC. Urinary tract infections due to Candida albicans. Rev Infect Dis 1982; 4(6): 1107-1118.

[15] Diaz Colodrero G, Altclas J, Jasovich A, Mikaelian G, Fiks G, Caro E. Microbiology and conservative surgery of serious infections of the diabetic foot. Enterm Infecc Microbiol Clin 1992; 10(8): 451-455.

[16] Grayson ML, Gibbons GW, Habershaw GM, Freeman DV, Pomposelli FB, Rosenblum BI, Levine E, Karchmer AW. Use of ampicillin/sulbactam versus imipenem/cilastatin in the treatment of limb-threatening foot infections in diabetic patients. Clin Infect Dis 1994; 18(5): 683-693.

[17] Lipsky BA, Pecoraro RF, Larson SA, Hanley ME, Ahroni JH. Out-patient management of uncomplicated lower-extremity infections in diabetic patients. Arch Intern Med 1990; 150(4): 790-797.

[18] Peterson LR, Lissack LM, Canter K, Fasching CE, Clabot SC, Gerding DN. Therapy of lower extremity infections with ciprofloxacin in patients with Diabetes mellitus, Peripheral vascular disease, or both. Am J Med 1989; 86(6Pt2): 801-808.

[19] Scheld WM, Mandell GL. Nosocomial pneumonia: pathogenesis and recent advances in diagnosis and therapy. Rev Infect Dis 1991; 13(Suppl 9): S743-751. 


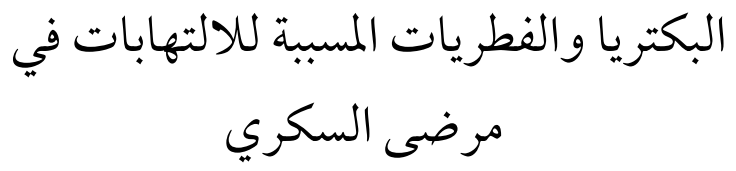

سليمان الشيخ و أيمن جوهرجي

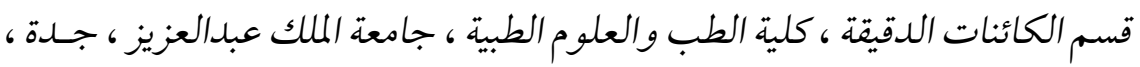

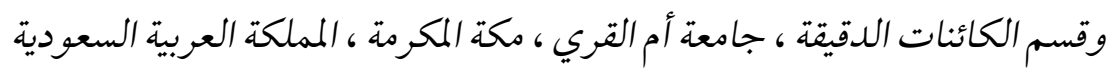

$$
\begin{aligned}
& \text { المستـخلص. لقـد تم جـمع ، } 10 \text { عينة مـن مرضى السكر خـلال مـدة }
\end{aligned}
$$

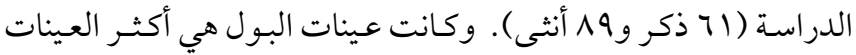

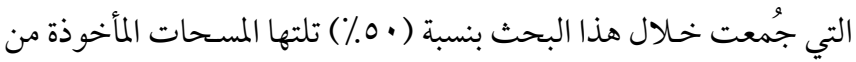

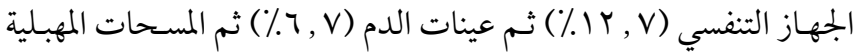

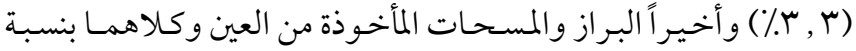

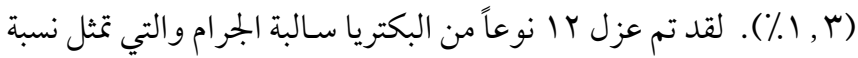

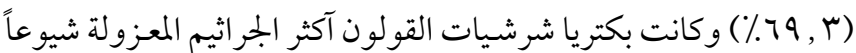

$$
\begin{aligned}
& \text { (\% r, V) }
\end{aligned}
$$

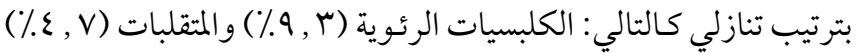

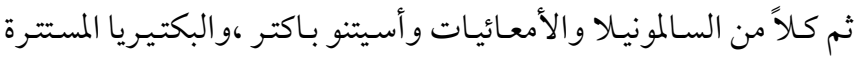

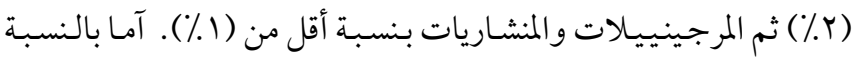

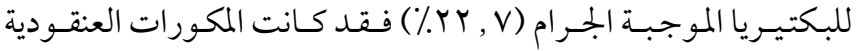

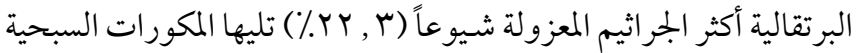

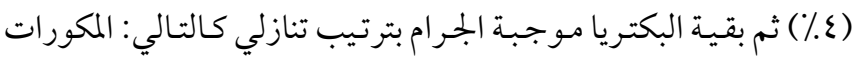

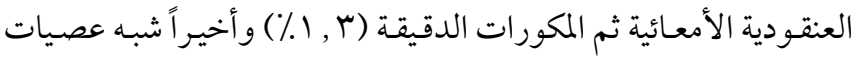

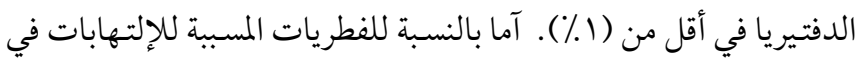

$$
\begin{aligned}
& \text { مرضى السكر فقد وجد أن المسبب الأساسي لها هي المبيضات. }
\end{aligned}
$$

